\title{
URUF DAN IMPLIKASINYA TERHADAP KEDUDUKAN NAFKAH ISTRI KARIR
}

\section{Harwis Alimuddin}

(Mahasiswa Program Doktoral, Konsentrasi Fikih Modern, UIN Ar-Raniry Banda Aceh)

\section{Abstract:}

The law should be changed because of the changes in the public's 'urf. Changes to the law are built on the basis of benefit, needs and principles of Shari'a which always adjust to the conditions of society. In order to maintain the balance principle of the rights and obligations of a husband and wife, the rights and obligations of a husband should be adapted to the prevailing development of the 'urf. After being adapted to the 'urf, the results of this research indicated that the career wife's living is not only obliged to the husband. Further more, the wife who has a career should participate in family income as a partner for her husband.

Hukum harus diubah karena perubahan urf publik. Perubahan hukum dibangun atas dasar manfaat, kebutuhan dan prinsip-prinsip syariah yang selalu menyesuaikan dengan kondisi masyarakat. Untuk menjaga keseimbangan prinsip hak dan kewajiban suami dan istri, hak dan kewajiban suami harus disesuaikan dengan perkembangan 'urf yang berlaku. Setelah disesuaikan dengan urf, hasil penelitian ini menunjukkan bahwa kehidupan istri karier tidak hanya wajib bagi suami. Lebih jauh lagi, istri yang memiliki karier harus berpartisipasi dalam pendapatan keluarga sebagai pasangan suaminya.

\section{Keywords: Uruf, Nafkah, Karier.}


24 |Rausyan Fíkr, Vol. 15 No. 1 Juni 2019: 23-62

\section{PENDAHULUAN}

Menjadikan uruf sebagai salah satu ruh fikih adalah sebuah keniscayaan. Teks-teks syariah (nass) semestinya harus dipahami berdasarkan konteks kapan dan di mana teks-teks syariah itu diartikulasikan. Pemahaman seperti inilah yang akan membuat fikih itu lebih aktual, lebih kontekstual (fiqh al-wāqi'), lebih dinamis, lebih responsif dan tidak membuat seorang mujtahid terkungkung dan terjebak dalam teks-teks parsial.

Salah seorang ulama kontemporer yang antusias mendukung teori uruf sebagai bagian dari piranti kemaslahatan adalah Muhammad Sa'ìd Ramaḍān al-Būti. Menurutnya, salah satu bukti kongkrit bahwa agama ini sangat mengedepankan kemaslahatan adalah adanya perhatian syariat Islam terhadap uruf dan kondisi masyarakat. Bahkan syariat telah menetapkan beberapa uruf yang ada pada Arab Jahiliyah era pra Islam, seperti uruf diyat dalam kasus pembunuhan, uruf kafaah dalam pernikahan, uruf pinjam meminjam dalam mu'ämalah, uruf membungkus ka'bah (kiswatul ka'bah) dalam ibadah, serta uruf-uruf lain yang dianggap terpuji pada zaman Jahiliyah.

Sejarah mencatat bahwa ijtihad yang dilakukan oleh para ulama sejak masa Sahabat selalu dipengaruhi dan bahkan didorong dan terikat dengan uruf dan lingkungan tempat mereka hidup. Akibatnya, mungkin sekali menyebabkan kesenjangan antara ketentuan fikih yang dilahirkan dalam suatu uruf dan kesadaran hukum dari masyarakat lain yang akan dimasukinya karena adanya perbedaan uruf. Sangat boleh jadi akan ada aturan fikih yang lahir dalam suatu uruf tertentu, sukar diterima oleh satu masyarakat dalam uruf yang berbeda karena dianggap tidak sesuai dengan uruf dan kebiasaan mereka. 


\section{Harwis Alimuddin, Urf dan Implikasinya terhadap Kedudukan| 25}

Bahkan menurut Alquran, semua Rasul diturunkan Allah untuk membimbing serta mengembalikan manusia kepada fitrah kemanusiaannya, agar tidak dikuasai atau dikendalikan oleh nafsu dan tidak disesatkan oleh iblis. Konsep keimanan semua rasul menyampaikan hal yang sama, mengajak manusia mengakui dan mengimani keesaan Allah swt. (QS. Alu 'Imrān/3 ayat 64). Adapun dalam masalah ibadah dan muamalah, uruf para rasul tersebut boleh jadi akan berbeda-beda (QS. al-Māidah/5 ayat 43, 37 dan 48), disesuaikan dengan lingkungan di mana mereka diutus. Alquran juga mengakui, bahwa isi dunia-dalam hal ini uruf dan peradaban yang ditemukan pada berbagai kalangan manusia, tidak ada yang tetap, semuanya dalam proses berubah dan berkembang secara terus menerus, karena demikianlah sifat dasar dari semua ciptaan Allah swt.

Salah satu cabang fikih yang tidak bisa dilepaskan dari perkembangan uruf adalah masalah nafkah. Fikih klasik menyatakan bahwa nafkah adalah kewajiban mutlak suami. Pemahaman ini didasari atas prinsip pemisahan harta antara harta suami dan harta istri. Hal ini juga didasari atas prinsip bahwa tugas seorang istri adalah mengurus rumah tangga dan cenderung tidak bekerja di luar rumah. Tugas seorang istri bukan sebagai pencari nafkah tetapi penerima nafkah.

Masalah yang muncul kemudian adalah, perkembangan zaman dan modernitas menggiring dan menuntut istri untuk bekerja, termasuk di luar rumah. Bahkan ada istri yang berpenghasilan lebih tinggi dari suami. Tuntutan standar kehidupan yang semakin tinggi, menjadi pemicu sebagian istri untuk ikut bekerja dan berkarier. Karena kebutuhan keluarga di zaman modern berbeda dengan kebutuhan keluarga di zaman dahulu. Pada masa klasik, kebutuhan primer rumah tangga belum sekompleks saat ini, sehingga pekerjaan suami masih memadai untuk memenuhi 
kebutuhan rumah tangga. Kebutuhan primer rumah tangga masih berkisar pada kebutuhan makanan, minuman dan pakaian. Tetapi saat ini, kebutuhan rumah tangga terutama di daerah perkotaan meningkat menjadi kebutuhan primer yang dahulu mungkin kebutuhan sekunder- bahkan kebutuhan tersier. Seperti kebutuhan biaya listrik, biaya cleaning service, biaya keamanan, biaya transportasi dan bahkan biaya telekomuniasi. Sehingga menuntut istri untuk ikut membantu mencukupi kebutuhan rumah tangga.

Pada aspek yang lain, uruf 'bekerja untuk perempuan' ini adalah implikasi dari gerakan feminisme yang ingin menyeratarakan laki-laki dan perempuan.Sehingga dalam hal bekerja pun mereka mengkampanyekan untuk mendapatkan kesempatan yang sama dengan laki-laki. Implikasi ini pun merambah keseluruh pelosok dunia termasuk Indonesia. Sehingga dalam pembentukan konstitusi negara pun dijunjung tinggi persamaan hak antara laki-laki dan perempuan, baik sosial maupun pemerintahan. Seperti yang tertuang dalam konstitusi UUD 1945 yang telah diamandemen. UUD pasal 28 F menyatakan, "Setiap orang berhak untuk berkomunikasi dan memperoleh informasi untuk mengembangkan pribadi dan lingkungan sosialnya, serta berhak untuk mencari, memperoleh, memiliki, menyimpan, mengolah, dan menyampaikan informasi dengan segala jenis saluran yang tersedia". Kata 'orang' dalam pasal ini berarti tidak ada pembeda antara laki-laki dan perempuan dalam mengembangkan lingkungan sosialnya.

UUD pasal $28 \mathrm{C}$ ayat (1) juga menyatakan, "Setiap orang berhak mengembangkan diri melalui pemenuhan kebutuhan dasarnya, berhak mendapatkan pendidikan dan memperoleh manfaat dari ilmu pengetahunan dan teknologi, seni dan budaya, demi meningkatkan kualitas hidupnya dan demi kesejahteraan ummat manusia". Demikian halnya dengan pasal 28 D ayat (3) pun 
Harwis Alimuddin, Urf dan Implikasinya terhadap Kedudukan| 27

menyatakan, "setiap orang berhak memperoleh kesempatan yang sama dalam pemerintahan". Sehingga terlihat dengan jelas bahwa konstitusi memberikan kesempatan yang sama untuk bekerja, baik di bidang sosial maupun di bidang pemerintahan, kepada semua warga negara tanpa membedakan antara laki-laki dan perempuan. Implikasinya, keinginan kaum perempuan untuk bekerja dan mengejar karier meningkat signifikan.

Implikasinya, dalam diskursus hukum Islam, paradigma pemisahan harta istri dan suami menjadi terkikis. Perubahan uruf menuntut perubahan paradigma pemisahan harta istri dan suami menjadi paradigma penyatuan harta istri dan suami (gono-gini). Sehingga pada akhirnya terbentuk dalam suatu Kompilasi Hukum Indonesia (KHI). Sebagaimana yang termuat dalam Kompilasi Hukum Islam di Indonesia (KHI) Bab XIII, pasal 85, dan pasal 88 sampai pasal 97 yang mengakui eksistensi harta bersama. Karena landasan penyatuan harta ini tidak ditemukan dalam nas khusus dan parsial, maka landasan yang paling logis adalah karena pertimbangan uruf demi mencapai kemaslahatan yang bersumber dari kebutuhan masyarakat.

\section{URUF DAN TRANSFORMASI HUKUM ISLAM}

Secara etimologi uruf berasal dari bahasa Arab al-'urf yang memiliki beberapa makna, ada makna majàzi dan ada makna

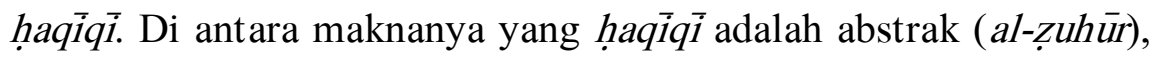
jelas (al-wud $\bar{u}$ ), ketinggian (al-irtifä) seperti kebaikan, keistimewaan dan apa yang dikenal baik oleh jiwa sebagai sebuah kebaikan. Adapun maknanya yang majazi, seperti makna indikator datangnya angin (a'räf al-rīh), indikator datangnya awan (a'räf alsihāab), indikator datangnya gemuruh (a'rāf al-ḍbāb), maksudnya adalah tanda-tanda kemunculannya. Kata uruf juga kerap dijadikan sebagai makna majàzì dari gelombang lautan. 
Sedangkan secara terminologi, uruf menurut al-Jurjāni adalah apa yang jiwa menjadi tentram dengannya dengan berlandaskan akal yang sehat dan diterima oleh tabiat. Menurut Wahbah al-Żuhaili, Uruf adalah apa yang telah menjadi kebiasaan manusia dan mereka praktekkan dalam setiap perbuatan yang terealisasi di antara mereka atau dalam lafal (bahasa) yang mereka ungkapkan untuk memberi makna tertentu dan lafal itu tidak dipahami oleh mereka selain makna tersebut. Oleh karena itu, uruf juga bermakna kebiasaan kolektif.Menurut Musțāfā Aḥmad alŻarqa, Uruf adalah kebiasaan mayoritas suatu komunitas dalam bertuturkata dan bertindak.

Landasan uruf sebagai latar belakang penemuan hukum adalah QS. Al-A'rāf/7 : 199; QS. Al-Nisā/4 : 115; QS. alBaqarah/2: 236; QS. al-Nūr/24: 58 dan QS. al-Māidah/5: 89. Landasan uruf dari Hadis adalah Hadis Rasulullah saw.

Diriwayatkan dari Zirri Ibnu Hubaisy dari 'Abdullah Ibnu Mas'ūd berkata: "sesungguhnya Allah swt. telah memperhatikan hati para hamba-Nya dan menemukan hati Muhammad saw. sebagai hati terbaik dari para hamba-Nya. Sehingga dibersikan dan diutus mengemban risalah-Nya. Allah swt. kemudian memperhatikan lagi hati hamba-Nya setelah menemukan hati Muhammad saw. kemudian Allah swt. menemukan hati para sahabat Rasulullah saw. lantas dijadikan wakil Nabi-Nya berperang membela agama-Nya. Maka perkara yang dilihat baik oleh ummat Muslim, perkara itu baik juga di sisi Allah swt. dan perkara yang dilihat buruk oleh ummat Muslim, perkara itu buruk pula di sisi Allah swt. Begitupun dengan Hadis Rasulullah saw. dari 'Āisyah beliau berkata:" Hindun putri 'Utbah istri Abū Sufyan masuk menghadap Rasulullah saw. seraya berkata : Ya Rasulullah sesungguhnya Abū Sufyān adalah seorang lelaki yang kikir. Dia tidak memberikan saya nafkah yang cukup untuk saya dan anak- 


\section{Harwis Alimuddin, Urf dan Implikasinya terhadap Kedudukan| 29}

anakku selain apa yang saya ambil dari sebagian hartanya tanpa sepengetahuannya. Apakah saya berdosa karena perbuatanku itu?, Rasulullah saw. bersabda: "Ambillah olehmu sebagian dari hartanya dengan cara yang baik secukupnya untukmu dan anakanakmu."

Fungsi uruf dalam penalaran hukum dapat dibagi menjadi tiga. Fungsi Pertama: Sebagai dalil (minimal sebagai latar belakang) untuk kebolehan melakukan atau tidak melakukan sesuatu ketika dalil nas tentang masalah tersebut tidak memadai atau bahkan tidak ada. Contoh untuk hal ini adalah beberapa transaksi dalam bab muamalat dan munakahat yang tidak diatur oleh Alquran atau Hadis Nabi. Misalnya saja kebolehan melakukan akad istisnna ', (memesan atau menempah barang). Dalam Hadishadis, jual beli cenderung diarahkan kepada bentuk tunai, barang yang tidak ada atau belum ada tidak boleh diperjualbelikan, dan kalau tetap dilakukan maka akad jual beli akan dianggap tidak sah. Tetapi pemesanan barang dianggap boleh karena ada jaminan bahwa barang yang akan dibeli/dipesan tersebut sudah diketahui sepesifikasinya, sehigga walaupun belum ada, dapata dianggap sudah ada. Begitu juga kebolehan menyerahkan uang panjar sebagai sebagai tanda sudah ada transaksi, dan uang itu akan hilang sekiranya pembeli membatalkan akad secara sepihak.

Fungsi Kedua: Sebagai dalil untuk menjelaskan makna lafal atau konsep yang digunakan Alquran, yang tidak memadai sekiranya dijelaskan atau diberi arti secara bahasa. Misalnya arti lafal atau konsep "keluarga (ahli)" dalam QS. al-Taḥrim/66: 6. Ulama berbeda pendapat dalam menafsirkan lafal (konsep) keluarga, karena lafal tersebut tidak akan jelas sekiranya diartikan hanya secara lugawiah (kebahasaan). Bahkan mungkin tidak terlalu berlebih-lebihan sekiranya dikatakan tidak dapat diartikan secara lugawiah, karena lafal keluarga selalu diartikan dengan uruf suatu 
masyarakat. Lafal (konsep) keluarga sangat bergantung kepada adat suatu masyarakat, sehingga isi (orang yang akan menjadi anggota) suatu keluarga akan berbeda antara satu masyarakat dengan yang lainnya. Budaya masyarakat Arab, panggilan seseorang kepada saudara ayahnya ('ammu, ammah) berbeda dengan panggilan yang digunakan kepada saudara ibunya (khāl, khālah). Sedangkan dalam sebagian masyarakat Indonesia panggilan tersebut sama. Dengan demikian, mungkin akan dapat diterima sekiranya banyak lafal yang berhubungan dengan kekerabatan dalam Alquran yang harus diartikan berdasarkan uruf karena sangat berkaitan dengan uruf masyarakat.

Fungsi ketiga: mendefinisikan perbuatan atau perkataan mukallaf. Contoh; ketika orang Aceh bersumpah atas nama Allah swt.: "hari ini saya tidak akan naik kereta", ternyata hari itu dia naik motor, maka orang Aceh ini sudah melanggar sumpahnya, sehingga wajib membayar kaffarah (denda sumpah). Sedangkan orang Makassar ketika bersumpah atas nama Allah swt. dengan kata yang sama: "hari ini saya tidak akan naik kereta", kemudian dia naik motor, maka orang Makassar ini tidak dianggap melanggar sumpahnya. Karena yang dimaksud dengan 'kereta' dalam uruf orang Aceh adalah motor. Sedangkan kata 'kereta' dalam uruf orang Makassar adalah kereta api. Dalam konteks ini, terlihat dengan jelas bahwa fungi uruf di sini adalah untuk mendefinisikan perbuatan atau perkataan mukallaf. Apakah dia termasuk orang yang melanggar sumpah atau tidak.

Islam mengakui eksistensi perubahan sebagai suatu realitas yang tidak bisa diingkari. Islam juga memberi posisi yang paling tepat demi memudahkan semua hal untuk berubah secara aman. Agama berjalan bersama beriringan dengan lajunya kehidupan. Tugas agama adalah mengawal perubahan secara benar untuk kemaslahatan hidup manusia. Cendikiawan Muslim harus 


\section{Harwis Alimuddin, Urf dan Implikasinya terhadap Kedudukan| 31}

merumuskan pendekatan dan metodologi yang tepat sesuai dengan konteks yang melingkupinya agar agama menjadi fungsional dan bisa membumi. Perubahan sosial budaya dan letak geografis menjadi variabel penting yang ikut mempengaruhi adanya perubahan hukum. Ibnu Qayyim al-Jauziyah menyatakan ungkapan monumental berikut ini:

Barang siapa yang memberikan fatwa kepada orang hanya berlandaskan buku-buku yang tertulis tanpa melihat perbedaan tradisi mereka, perbedaan waktu, kondisi dan konteks yang melingkupi mereka, maka dia telah sesat dan menyesatkan, bahkan kejahatan mufti seperti ini lebih besar dibanding kejahatan seorang dokter yang mengobati semua orang dari latar belakang daerah, tabiat, situasi dan tempat yang berbeda-beda dengan hanya berlandaskan pada suatu buku kedokteran. Dokter atau mufti yang bodoh seperti demikian adalah orang yang paling berbahaya bagi agama dan kesehatan manusia.

Salah satu bukti konkret betapa faktor lingkungan sosial budaya berpengaruh terhadap hukum Islam adalah munculnya dua pendapat Imam Syafi'i yang dikenal dengan qaul qadim dan qaul jadid. Pendapat lama (qaul qadim) adalah pendapat hukum Imam Syafi'i ketika beliau berada di Mesir. Perbedaan pendapat hukum dalam masalah yang sama dari seorang Mujtahid Imam Syafi'i jelas disebabkan faktor struktur sosial, budaya, letak geografis yang berada antara daerah Iraq dan Mesir.

Secara historis, pemikiran bidang hukum Islam sesungguhnya memperlihatkan kekuatan yang dinamis dan kreatif dalam mengantisipasi setiap perubahan dan persoalan- persoalan baru. Hal ini dapat dilihat dari munculnya sejumlah madzhab hukum yang memiliki corak sendiri-sendiri sesuai dengan latar belakang sisio-kultural dan politik di mana madzhab itu tumbuh 
dan berkembang. Warisan monumental yang sampai sekarang masih memperlihatkan akurasi dan relevansinya adalah kerangka metodologi penggalian hukum yang mereka ciptakan. Dengan perangkat metodologi tersebut, segala permasalahan bisa didekati dan dicari legalitas hukumnya dengan metode qiyas, maslahah almursalah, istihsan, istishab, dan uruf. Dalam posisi demikian, hukum Islam akan berfungsi sebagai rekayasa sosial (social engineering) untuk melakukan perubahan dalam masyarakat.

Untuk menempatkan hukum pada posisi yang betul-betul fungsional dalam menghadapi setiap perubahan sosial, diperlukan terobosan metodologis disertai kemampuan membaca fenomena zaman. Banyak perangkat ilmu bantu yang bisa menopang perumusan hukum menjadi aplikatif, seperti ilmu-ilmu tafsir, sejarah, dan tata bahasa Arab. Diharapkan melalui pendekatan konvergensi antara ilmu usul fikih dan ilmu-ilmu lainnya akan dapat mengurangi formalisme hukum Islam.

Pemaknaan hukum Islam tidak harus dilihat dari perspektif nilai saja, tetapi perlu dicari keterkaitan secara organik dan struktural dalam kehidupan sosial. Dibutuhkan transformasi pemikiran hukum Islam, tidak hanya dilihat sebagai fenomena keagamaan saja. Transformasi pemikiran hukum Islam di Indonesia merupakan suatu pergumulan kreatif antara Islam dengan masyarakat Indonesia, antara nilai-nilai Islam dengan kenyataan struktural masyarakat. Oleh karena itu, maka program pembaruan pemikiran hukum Islam adalah suatu bagian yang tidak terpisahkan dari proses kehidupan masyarakat yang selalu berubah.

Akan tetapi, untuk melakukan upaya pembaruan pemikiran hukum Islam (Fikih) diperlukan beberapa syarat; pertama, adanya tingkat pendidikan yang tinggi dan keterbukaan dari masyarakat muslim; kedua, hukum Islam (Fikih) harus dipandang sebagai 
Harwis Alimuddin, Urf dan Implikasinya terhadap Kedudukan| $\mathbf{3 3}$

variasi suatu keragaman yang bersifat partikular yang selalu dibatasi oleh dimensi ruang dan waktu; ketiga, memahami faktor sosio- kultural dan setting politik yang melatarbelakangi lahirnya suatu produk hukum agar dapat memahami partikularisme dari pemikiran hukum tersebut; keempat, mengorientasikan istinbat hukum dari aspek qaulan (materi hukum) kepada aspek manhajan (kerangka metodologis). Selain itu, perlu juga memahami pemikiran hukum yang tidak dibatasi sekat-sekat madzhab. Keterbatasan alternatif yang dibingkai dengan sekat mazhab akan menghasilkan produk pemikiran yang rigid (kaku) dan akan mempersulit upaya pembaruan hukum Islam itu sendiri.

\section{PERBEDAAN URUF KLASIK DENGAN URUF MODERN}

Sejarah menginformasikan bahwa sebelum turunnya Alquran terdapat sekian banyak peradaban besar, seperti Yunani, Romawi, India dan Cina. Dunia juga mengenal agama-agama seperti Yahudi, Nasrani, Buddha dan Zoroaster. Masyarakat Yunani yang terkenal dengan pemikiran-pemikiran filsafatnya tidak banyak membicarakan tentang hak dan kewajiban wanita. Wanita-wanita ditempatkan (disekap) dalam istana-istana. Di Kalangan bawah, nasib wanita sangat menyedihkan. Mereka diperjualbelikan, sedangkan yang sudah berumah tangga sepenuhnya berada di bawah kekuasaan suaminya. Mereka tidak memiliki hak-hak sipil, bahkan hak waris pun tidak ada. Pada puncak peradaban Yunani, wanita diberi kebebasan sedemikian rupa untuk memenuhi kebutuhan dan selera laki-laki. Hubungan seksual yang bebas tidak dianggap melanggar kesopanan, tempattempat pelacuran menjadi pusat kegiatan politik dan seni. Patungpatung telanjang di negara-negara barat adalah bukti atau sisa pandangan itu. Dalam pandangan mereka, dewa-dewa melakukan hubungan gelap dengan rakyat bawahan, dari hubungan gelap itu lahirlah 'Dewi Cinta' yang terkenal dalam peradaban Yunani. 
Peradaban Romawi, wanita sepenuhnya berada di bawah kekuasaan ayahnya. Setelah menikah, kekuasaan tersebut berpindah ke tangan suaminya. Kekuasaan ini mencakup kewenangan menjual, mengusir, menganiaya, dan membunuh. Keadaan tersebut berlangsung sampai abad ke-6 Masehi. Segala hasil usaha wanita, menjadi hak milik keluarganya yang laki-laki. Pada rezim Kaisar Constantine terjadi sedikit perubahan yaitu dengan diundangkannya hak pemilikan terbatas bagi wanita. Dengan catatan bahwa setiap transaksi harus disetujui oleh keluarga (suami atau ayah).

Menurut Quraish Shihab, kedudukan wanita dengan kondisi seperti itu berlangsung sampai menjelang bahkan sampai Alquran sudah diturunkan. Sehingga keadaan sosio kultural seperti itu akan mempengaruhi pemahaman sementara terhadap redaksi petunjuk Alquran. Quraish Shihab mengemukakan contoh penafsiraran yang terkontaminasi dengan sosio kultural ini, yaitu ketika para mufassir menafsirkan kata 'al nafs' dalam QS. al-Nisa 4/1. Quraish Shihab mengemukakan bahwa banyak sekali pakar tafsir yang memahami kata 'al-nafs' dengan Adam. Seperti Jalaluddin al-Suyūṭi, Ibnu Katsìr, al-Qurțubi, al-Biqāi, Abū al-Su'ūd. Bahkan al-Ṭabarsi, salah seorang ulama Syiah (abad ke-6 H) mengemukakan dalam tafsirnya bahwa seluruh ulama tafsir sepakat mengartikan kata tersebut dengan Adam.

Kondisi sosio-kultural perempuan era pra Islam ini, mempengaruhi corak penafsiran teks-teks syariah. Akibatnya, kedudukan perempuan setelah Islam datang pun masih membutuhkan waktu yang cukup lama untuk mendapatkan posisi yang setara dan seimbang dengan laki-laki sesuai dengan fitrahnya. Sampai pada masa kekhalifahan pun perempuan masih termarjinalkan. Dalam pemerintahan, mulai dari pemimpin (khalifah) sampai pegawai pemerintahan, semuanya dipegang oleh 
Harwis Alimuddin, Urf dan Implikasinya terhadap Kedudukan| 35

laki-laki. Perempuan tidak pernah diberi jabatan dalam pemerintahan. Setiap khalifah yang meninggal maka selalu digantikan dengan putranya laki-laki atau saudaranya laki-laki. Artinya, tidak ada satu khalifah pun mulai dari as-Saffah (749 M $754 \mathrm{M})$ sampai al-Mutawakkil (847 M - $861 \mathrm{M})$ yang dipilih dari kaum perempuan. Begitu juga, ketika khalifah terpilih maka khalifah tersebut juga memilih pegawai pemerintahan dari kaum laki-laki, misalnya pemilihan Khālid bin Barmak sebagai wazìr oleh al-Manșūr.

Kedudukan perempuan yang dinomor duakan berlangsung sampai masa kodifikasi fikih Mazhab. Keadaan itu dipastikan akan mempengaruhi corak pemikiran fikih. Karena para mujtahid tidak berijtihad pada ruang yang hampa. Hasil ijtihad mereka adalah manifestasi dialog antara teks-teks syariah dengan realitas yang ada. Baik realitas sosio-kultural maupun realitas letak geografis di mana mereka berada.

Imam Syafi'i misalnya, selama tinggal di Mesir (199 H $204 \mathrm{H}$ ), keadaan mayoritas perempuannya secara akademis sangatlah memprihatinkan. Perempuan pada waktu itu hanyalah sebagai pendamping laki-laki yang tugasnya tidak lebih dari ibu rumah tangga. Perempuan hanya bertugas untuk berhias, menyiapkan makanan, mengurus anak dan melakukan pekerjaan rumah yang lain. Mereka tidak pernah ikut andil dalam kegiatan di luar rumah, sehingga mereka pun hanya menjadi teman setia lakilaki yang tinggal mengikuti intruksi dari apa yang menjadi perintah laki-laki.

Berbeda halnya dengan kondisi uruf di Indonesia. Survei yang dilakukan oleh Grant Thornton menunjukkan Indonesia menempati posisi ke enam tertinggi di dunia dari jumlah persentase wanita karier. Survei itu juga mengungkap bertambahnya posisi 
senior pada perusahaan di dunia yang diisi oleh perempuan. Secara global, Eropa Timur menjadi kawasan yang paling dominan memberikan kesempatan kepada perempuan memimpin dalam sebuah perusahaan, yaitu 35 persen. Secara mengejutkan, kawasan Asia Tenggara menempati posisi kedua di dunia yang memberikan posisi tinggi dalam sebuah perusahaan kepada perempuan, yaitu 34 persen. Berdasarkan hitungan negara, Rusia menjadi negara dengan persentase tertinggi yang memberikan posisi tinggi di perusahaan kepada perempuan, yaitu 45 persen. Berikutnya disusul oleh Filipina dan Lithuania dengan 39 persen, Estonia dan Thailand dengan 37 persen. Untuk Indonesia sendiri, 36 persen posisi senior di perusahaan dipegang oleh perempuan. Survei tersebut menunjukkan sebesar 20 persen posisi General Manager atau Office Manager dikendalikan oleh perempuan. Namun, tidak sedikit perempuan yang memegang posisi lebih penting, seperti CEO dengan angka 17 persen, direktur sebesar 10 persen, Chief Financial Officer (CFO) sebanyak tujuh persen, dan Chief Operating Officer (COO) sebanyak 3 persen.

Berdasarkan data Badan Pusat Statistik (BPS), pekerja perempuan di Indonesia mengalami peningkatan setiap tahun. Persentase jumlah pekerja perempuan mencapai lebih dari 50 persen. Pada sektor tertentu seperti jasa kemasyarakatan, jumlah pekerja perempuan hampir menyamai jumlah pekerja laki-laki.

Di Indonesia, dalam adat pelbagai suku bangsa Nusantara, suami dan istri sama-sama bekerja, keduanya saling membantu untuk mencukupi kebutuhan rumah tangga. Secara umum, dalam adat pelbagai suku tersebut tidak dikenal adanya kewajiban suami untuk menyediakan pembantu dalam mengurus pekerjaan-pekerjan domestik. Karena pekerjaan domestik sudah menurut anggapan masyarakat Indonesia adalah pekerjaan istri, sedangkan suami bertuga bekerja di luar rumah. karena keduanya (suami-istri) 


\section{Harwis Alimuddin, Urf dan Implikasinya terhadap Kedudukan| 37}

bekerja, penghasilan atau kekayaan yang mereka peroleh pun menjadi milik bersama. Akibat lanjutnya, apabila terjadi perceraian maka harta bersama harus dibagi antara mereka berdua dan ketika salah satu pihak meninggal dunia, maka hanya harta bersama yang menjadi bagian (milik) orang yang meninggal yang akan dibagikan sebagai warisan.

Berangkat dari realitas di atas, maka dapat disimpulkan bahwa setidaknya ada tiga hal yang membedakan antara uruf klasik pra Islam -yang berlanjut hingga masa kodifikasi fikih Mazhabdengan uruf modern (saat ini), khususnya di Indonesia, yaitu:

Pertama: mengenai kedudukan perempuan. Uruf klasik perempuan cenderung terisolir di dalam rumah sehingga mereka tidak mendapat kesempatan untuk memberdayakan diri dan mendapatkan kesempatan berkarya di ruang publik. Konsekuensinya, mereka tidak bisa mandiri dan selalu bergantung terhadap nafkah suami. Sedangkan dalam uruf modern, perempuan diberdayakan, dididik sehingga memiliki skill yang dibutuhkan oleh publik. Skill dan pendidikan yang dimilikinya membuat mereka tampil di publik dan mendapatkan penghasilan. Dampak positinya, mereka menjadi mandiri dan tidak lagi bergantung dengan nafkah suami.

Kedua: mengenai realitas nafkah. Para istri pada masa klasik cenderung menjadi objek penerima nafkah saja. Sedangkan dalam uruf modern, khususnya di Indonesia, banyak istri yang tidak lagi menerima nafkah, bahkan ikut serta dalam nafkah keluarga. Tidak sedikit yang memiliki penghasilan melebihi pengahasilan suami. Khususnya mereka yang berkarier.

Ketiga: mengenai harta gono-gini. Uruf klasik relatif tidak mengenal penyatuan harta suami dan harta istri. Sedangkan uruf di Indonesia, perempuan yang mengurus rumah tangga sekalipun, 
tetap dianggap bekerja dan memiliki andil dalam menghasilkan harta rumah tangga. Oleh karena itu, perempuan yang mengurus rumah tangga pun berhak mendapatkan dan memiliki separuh harta dari harta yang dihasilkan sejak pernikahan terjadi. Apabila terjadi perceraian, mereka memiliki hak untuk menuntut haknya.

Kondisi uruf yang berbeda ini membutuhkan transformasi hukum untuk mengakomodir realitas yang ada. Supaya fikih menjadi hukum yang hidup di masyarakat (living law), bukan menjadi hukum mati yang hanya ada dalam buku-buku fikih. Hal ini bukan berarti menganggap bahwa buku fikih yang telah dikodifikasi oleh ulama terdahulu itu adalah sesuatu yang keliru. Buku-buku fikih mereka sangat sesuai dengan zamannya. Tetapi ketika akan di bawa ke zaman dan letak geografis yang berbeda, maka saat itulah dibutuhkan penyesusuian dan transformasi hukum.

\section{ADAPTASI URUF DENGAN KONSEP QAWWAMAH DAN NAFKAH}

Berdasarkan kitab Mu'jam diperoleh informasi bahwa kata 'al-rijär dengan berbagai derivasinya digunakan dalam Alquran sebanyak 28 kali. Kata 'al-Nisä' dengan berbagai ragamnya digunakan sebanyak 59 kali. Kata 'al-Talāq' dalam Alquran digunakan dengan berbagai derivasinya sebanyak 14 kali- 10 kali digunakan dalam bentuk fi'il dan 4 kali digaunakan dalam bentuk isim. Kata ' al-ujur' digunakan sebanyak 6 kali yang terdapat dalam 5 surah. Sedangkan kata al-Aulād dignakan sebanyak 63 kali- 7 kali digunakan dalam bentuk fi'il dan 56 kali menggunakan bentuk isim.

Berangkat dari langkah awal di atas, maka ayat-ayat Alquran yang berkaitan dengan hak dan kewajiban suami istri dapat diklasikfikasi. Pengklasifikasian ini juga merujuk kepada 
Harwis Alimuddin, Urf dan Implikasinya terhadap Kedudukan| 39

penjelasan Wahbah al-Zuhaili dan Sayyid Sābiq di mana keduanya membagi hak suami istri menjadi tiga kategori yakni hak suami, hak istri dan hak bersama.

Setelah pengklasifikasian di atas di elaborasikan dengan kata-kata kunci dalam Alquran yang berkaitan dengan hak dan kewajiban suami istri, ditemukan bahwa di dalam Alquran, terdapat 23 ayat yang berbicara tentang hak dan kewajiban suami istri dan 10 ayat ayat di antaranya diiringi dengan kata ma'rüfyang secara gramatikal merupakan bagian dari kata uruf. Alquran dengan kemukjizatan bahasanya menunjukkan bahwa hal ini bukanlah sesuatu yang kebetulan. Fakta ini mengindikasikan bahwa hak dan kewajiban suami istri dijelaskan di dalam nas, tetapi dalam terapannya harus diadaptasikan dengan perkembangan uruf yang berlaku.

Dinamika tentang hak kepemimpinan suami tidak bisa dilepaskan dari tafsiran para ulama tentang kata 'qawwām' dalam QS. al-Nisa/4: 34. Menurut Quraisy Shihab seseorang yang melaksanakan tugas atau apa yang diharapkan darinya dinamai qāim. Kalau dia melaksanakan tugas itu sesempurna mungkin, berkesinambungan dan berulang-ulang dia dinamai qawwām. Menerjemahkan kata 'qawwām' dengan pemimpin belum menggambarkan seluruh makna yang dikehendaki, meskipun harus diakui bahwa kepemimpinan merupakan satu aspek yang dikandungnya. Atau dengan kata lain, dalam pengertian 'kepemimpinan' tercakup pemenuhan kebutuhan, perhatian, pemeliharaan, pembelaan, dan pembinaan. Oleh karena itu, perlu digaris bawahi bahwa qawwāmah (kepemimpinan) yang dianugerahkan oleh Allah swt. kepada suami tidak boleh mengantarkannya kepada kesewenang-wenangan. Karena Alquran menganjurkan musyawarah dalam menyelesaikan setiap persoalan yang dihadapi keluarga. 
Pendapat Quraish Shihab sejalan dengan interpretasi Syeikh Muhammad 'Abduh. Menurutnya, kata 'qawwām' di dalam ayat ini bermakna kepemimpinan yang mengarahkan, membimbing, mendampingi dan mengayomi tanpa unsur paksaan dan kesewenang-wenangan. Muhammad 'Abduh juga menambahkan bahwa kelebihan yang diberikan kepada laki-laki dan perempuan bukan kelebihan secara mutlak. Hal itu hanya menunjukkan bahwa laki-laki dan perempuan seperti satu tubuh yang utuh. Laki-laki berperan sebagai kepada dan perempuan sebagai badan. Tetapi tidak bisa diklaim bahwa kepala lebih penting daripada badan, dan sebaliknya demikian. Kepala dan badan keduanya adalah organ yang vital dalm jasad manusia.

Ketika Alquran menetapkan tugas kepemimpinan itu, hal tersebut dinyatakan sebagai sebagai sebab dari dua hal pokok. Pertama: karena adanya keistimewaan yang berbeda pada masingmasing jenis kelamin, tetapi dalam konteks qawwāmah, keistimewaan yang dimiliki oleh laki-laki lebih sesuai untuk menjalankan tugas tersebut dibandingkan perempuan. Kedua: Kerena para suami telah menafkahkan sebagian harta mereka. Hal ini berarti jika keduanya, yakni kemampuan qawwāmah dan kemampuan memberi nafkah, tidak dimiliki oleh seorang suami, atau kemampuan istri melebihi kemampuan suami dalam hal keistimewaan-misalnya karena suami sakit-bisa saja kepemimpinan rumah tangga beralih kepada istri, tetapi ini dengan syarat kedua faktor di atas tidak dimiliki oleh suami. Jika suami tidak mempu memberi nafkah tetapi tidak mengalami gangguan dari segi keistimewaan yang dibutuhkan dalam kepemimpinan, istri belum boleh mengambil alih kepemimpinan itu.

Sedangkan Mụ̣ammad Syaḥrūr lebih cenderung mengartikan kata 'qawwām' sebagai 'orang yang memperbaiki urusannya' sesuai dengan asal katanya secara gramatikal 'qāma 
Harwis Alimuddin, Urf dan Implikasinya terhadap Kedudukan| 41

'ala al-amri ai ahsanahu’'. Muhammad Syaḥūr juga mengkritisi tafsiran para mufassir yang menafsirkan potongan ayat 'bima faḍdalallāhu ba'duhum 'ala ba'din' dengan tafisran 'karena Allah telah melebihkan sebagian laki-laki terhadap sebagian sesuai dengan kodrat penciptaannya'. Menurutnya, kelebihan yang dimaksudkan dalam ayat ini bukan dikhususkan kepada lelaki saja, tetapi bisa saja juga diberikan kepada perempuan sesuai dengan kemampuannya masing-masing. Seandainya kelebihan yang dimaksudkan di situ adalah kelebihan yang disebabkan oleh kodrat penciptaannya, maka Allah swt. akan menggunakan kalimat 'alzukūr qawwāmūna 'alā al ināṣ'. Oleh karena itu, menurutnya kelebihan itu bukan karena kodrat penciptaannya tetapi karena kemampuannya.

Muhammad Sa’ìd Ramaḍān al-Būṭi memiliki pendapat yang lebih moderat. Menurutnya, makna kepemimpinan dalam ayat ini adalah kepemimpinan yang melindungi (ri'ayah) dan bukan kepemimpinan yang menguasai. Pemimpin yang mengayomi itu tidak mesti harus dipilih dari orang yang lebih tinggi derajatnya, tetapi yang terpenting adalah orang yang mampu bertanggung jawab terhadap orang-orang yang dipimpinnya.

Menggunakan alur berpikir ini, maka dapat disimpulkan bahwa kemampuan memimpin dan menafkahi dalam suatu rumah tangga tidak selamanya didominasi oleh suami, tetapi bisa saja didominasi oleh istri. Sehingga apabila hal itu terjadi, maka hak kepemimpinan itu bisa saja dimiliki oleh istri. Dengan demikian sejatinya kepemimpinan itu bukanlah hak mutlak suami tetapi dimiliki oleh suami dan istri secara besama-sama sebagai mitra.

Mengenai konsep kepemimpinan ada tiga dinamika yang perlu menjadi fokus masalah, yaitu ketaatan istri (qānitāt); definisi nusyüz, dan izin memukul (idribūhunna). Ketiga masalah ini ada 
dalam ayat yang sama dengan konsep kepemimpinan, yaitu QS. alNisā/4: 34 .

\section{Pertama: Ketaatan Istri (Qānitāt)}

Penafsiran ulama klasik cenderung berpandangan bahwa istri mempunyai kewajiban untuk taat kepada suami sebagai pemimimpin rumah tangga. Hal ini dipahami dari QS al-Nisā/4: 34. Kata 'qānițat' dalam ayat ini menurut Ibnu Kasīir adalah istri-istri yang taat kepada suaminya secara mutlak dalam hal-hal yang patut dan tidak menjerumuskan kepada kemaksiatan.Hal ini menunjukkan bahwa Ibnu Kasiir masih cenderung memandang bahwa istri selehah adalah istri yang taat kepada suaminya.

Demikian halnya dengan al-Qurțubī. Menurut al-Qurtubi, ayat ini adalah kalimat informasi (jumlah khabariyyah) tetapi bermakna perintah (al-amr). Maksudnya adalah perintah kepada para istri untuk mentaati suaminya dalam menunaikan hak-hak suaminya.

Al-Marāgi sebagai penafsir akhir abad ke 19 pun masih memilih penafsiran yang memandang bahwa istri salehah adalah istri yang taat kepada suaminya. Menurut al-Marāgi, kata 'alqunüt' berarti ketentraman dan ketaatan kepada Allah dan kepada suami (al-qunüt huwa al-sukūnu wa al-ta'at lillāhi wa lil ażwāj).

Ibnu 'Asyūr memiliki penafsiran yang lebih moderat. Menurut Ibnu 'Asyūr, kata 'qānitāt' bukan bermakna istri-istri yang taat kepada suami, melainkan istri-istri yang taat kepada Allah swt. karena kata 'qunüt' itu bermakna ibadah kepada Allah swt. Hal ini menunjukkan bahwa istri-istri yang taat itu adalah yang takut kepada Allah swt. Oleh karena itu Allah swt menggandengkannya dengan lafal 'ḥăfizătun lilgaibì (memelihara diri ketika suaminya tidak ada). Istri yang memelihara dirinya ketika suaminya ada, memungkinkan dua hal, menjaga diri karena 
Harwis Alimuddin, Urf dan Implikasinya terhadap Kedudukan| $\mathbf{4 3}$

takut kepada suaminya atau menjaga diri karena takut kepada Allah swt. Tetapi ketika suaminya tidak ada, hanya ada satu kemungkinan. Yaitu memelihara diri karena takut kepada Allah swt. Hal ini menunjukkan bahwa kata kata 'qānităt' di sini bermakna istri-istri yang taat kepada Allah swt.

Muhammad Syaḥrūr sebagai penafsir modern memiliki penafsiran yang lebih berani dan lebih maju. Menurut Syahrūr kata 'ṣălihạt' atau istri salehah itu adalah istri yang memiliki qawwāmah. Alasan logisnya, karena ayat ini berbicara pada konteks qawwāmah, bukan pada konteks ibadah kepada Allah swt. Hal ini menunjukkah bahwa menurut Syahrūr bahwa qawwāmah itu, bukan hanya mampu dilakukan oleh suami tetapi istri juga.

Penafsiran yang mengharuskan kepatuhan istri kepada suami sebagaimana kepatuhan bawahan kepada atasan adalah penafsiran yang sangat terpengaruh oleh budaya patriarki. Penafsiran-penafsiran ini tampak membatasi hak-hak pribadi pribadi perempuan sebagai seorang manusia. Hal ini seakan-akan hubungan antara suami dan istri adalah hubungan antara seorang hamba sahaya dan tuannya. Pemahaman ini cenderung dapat diterima di awal kedatangan Islam ketika perempuan baru dalam tahap mengalami pergeseran status dari masa Jahiliyyah. Tetapi ketika diterjemahkan di konteks saat ini, maka penafsiran ini perlu ditinjau ulang dengan menyesuaikannya dengan uruf yang berlaku.

Kepatuhan istri kepada suami tidak diartikan sebagai kewenangan suami memerintah istri secara otoriter, diktator dan menjadikan istri sebagai bawahan suami. Kepatuhan istri lebih tepat diartikan sebagai ketaatan yang dilakukan karena Allah yang didasarkan atas cinta dan kasih sayang.

Kedua: Definisi Nusyüż 
44 Rausyan Fikr, Vol. 15 No. 1 Juni 2019: 23-62

Secara etimologi kata nusyūz bermakna 'tinggi' (altaraffu') dan 'kebangkitan' (al-nuhūọ). Oleh karena itu dataran tinggi bumi disebut 'nasyażu al-arḍi . Maknanya secara bahasa berkisar antara 'kegoncangan' (al-ị̣tirāb) dan 'saling berjauhan' (al-tabā'ud).

Sedangkan secara terminologi, definisi Nusyüż yang umum dipahami selama ini adalah keluarnya istri dari ketaatan kepada suaminya mengenai hak-hak suaminya dan kewajibannya sebagai istri.

Wahbah al-Zuhaili menyebutkan 6 hak terpenting suami, yaitu: hak dipatuhi; dijaga amanahnya; diperlakukan dengan baik; mendidik istri; menyuruh mandi junub; ditemani melakukan perjalanan.

Menurut Ibnu 'Āsyūr, nusyüż adalah kebencian terhadap suami yang kadangkala disebabkan oleh buruknya akhlak istri. Kadangkala juga disebabkan oleh buruknya akhlak suami. Atau mungkin juga disebabkan karena istri menginginkan menikah dengan lelaki yang lain.

Muhammad Syaḥrūr mendefinisikan 'nusyūz' dengan keluarnya istri dari batas-batas qawwāmah yang didasari atas cinta dan kasih sayang (al-khurüju 'an khațti al-qawwāmah bi almawaddati wa al-rahmah). Menurut Syahrūr, kata 'nusyüz' itu adalah antonim dari kata 'qunūt'. Syahrūr juga mengkritisi pendapat ulama yang memandang bahwa nusyūz adalah pembangkangan dan kedurhakaan istri terhadap suaminya karena dua faktor. Pertama: karena ayat ini berbicara tidak berbicara tentang ketaatan istri kepada suaminya. Kedua: karena dalam bahasa Arab kata 'al-nusyūs' bermakna 'keluar' dan 'berceraiberai' secara umum (al-khurūj wa al-tafarruq 'umūman). 
Harwis Alimuddin, Urf dan Implikasinya terhadap Kedudukan| 45

Definisi nusyüż yang disebutkan oleh Ibnu 'Āsyūr dan Muhammad Syahrūr lebih sesuai dengan konsep kemitraan dalam rumah tangga. Karena definisi keduanya tidak menempatkan istri sebagai bawahan yang harus taat kepada suami. Karena tampak dalam definisi Ibnu 'Āsyūr, nusyüż tidak disebabkan karena ketidak taatan istri kepada suaminya, melainkan karena buruknya akhlaknya atau akhlak suaminya. Mungkin juga karena dia ada keinginan lain yang menyebabkan dia membenci suaminya. Demikian halnya dengan definisi Syaḥrūr, karena defininsinya memandang bahwa istri memiliki kedudukan yang sama dengan suami dalam urusan qawwāmah, sehingga istri dan suami samasama memungkinkan untuk keluar dari batas qawwämah dan itulah yang disebut nusyüz.

\section{Ketiga: Definisi Memukul Istri (Idribūhunna)}

Tafsir dan fikih klasik cenderung memberikan tiga tahapan solusi istri yang nusyüż. Tahapan menasehati; pisah ranjang dan memukul. Tahapan ini diapahami dari QS. al-Nisa/4: 34. Ayat ini sering dijustifikasi sebagai ayat yang membolehkan memukul istri. Menurut al-Qurțubi, pukulan yang dimaksudkan dalam ayat ini adalah pukulan yang mendidik, pukulan yang tidak melukai, yaitu yang tidak mematahkan tulang dan yang tidak meningalkan bekas seperti lebam, bengkak dan semacamnya.Pendapat yang sama dikemukakan oleh Ibnu Kasìir.Al-Zamakhsyari menambahkan bahwa tidak boleh memukul di wajah.Muhammad 'Abduh memberikan contoh memukul yang tidak menyakiti, yaitu seperti memukul dengan siwak atau benda kecil lainnya yang tidak menyakiti.

Kesimpulannya, mereka masih cenderung mengartikan lafal 'ḍaraba' dalam ayat ini dengan makna 'memukul'. Implikasinya, pemahaman fikih yang berkembangpun membolehkan suami 
memukul istrinya dengan syarat pukulan itu adalah pukulan yang mendidik dan tidak melukai.

Pemahaman ini dibangun atas uruf yang cenderung mendomestikkan perempuan. Pergeseran uruf yang tidak lagi mendomestikkan perempuan, membutuhkan perluasan makna dari kata 'daraba'. Perintah 'idribūhunna' dalam ayat ini menurut Quraish Shihab dapat diartikan memukul ketika kedudukan suami sebagai pemimpin dan istri sebagai bawahan. Tetapi ketika zaman sudah berubah di mana istri tidak lagi ditempatkan sebagai bawahan, maka konsep 'ḍaraba' tidak lagi dilaksanakan dengan cara memukul secara fisik. Tetapi cukup dengan memberi isyarat. Menurut Quraish Shihab, untuk konteks masa kini, khususnya di kalangan terpelajar, pemukulan bukan lagi satu cara yang tepat.

Pendapat Quraish Shihab ini diperkuat dengan penyataan Ibnu 'Asyur dalam tafsirnya:

"Jika pemerintah mengetahui bahwa suami tidak bisa menempatkan sanksi-sanksi syariat ini di tempatnya yang semestinya dan tidak mengetahui batas-batas yang wajar, maka dibenarkan bagi pemerintah untuk menghentikan sanksi ini dan mengumumkan bahwa barang siapa yang memukul istrinya, maka akan dijatuhi hukuman. Hal ini agar tidak berkembang luas tindakan-tindakan yang membahayakan istri, khususnya di kalangan mereka yang tidak bermoral."

Selain itu, Ibnu 'Asyūr juga mengutipkan pena'wilan 'Atha tentang makna 'daraba' ini. Menurut 'Atha ta'wil 'idribūhunna' dalam ayat ini adalah 'marah kepada mereka'. Oleh karena itu, suami tidak boleh memukul istrinya, melainkan hanya boleh marah kepada mereka.

Menurut Syahrūr membantah pendapat ulama yang mengartikan kata 'daraba' dengan memukul. Menurut Syaḥrūr, 
Harwis Alimuddin, Urf dan Implikasinya terhadap Kedudukan| 47

'memukul' hanya salah satu makna dari kata 'ḍaraba'. Makna yang lain adalah 'memberikan contoh' (darbu al-amśal); 'berjalan di muka bumi' (al-darbu fí al-arḍi) dan 'menghitung uang' (al-ḍarbu al-nuqūd). Menurut Syahrūr, ayat ini harus dipahami dengan melihat Hadis-hadis yang melarang memukul istri.

Penafisran ini, seirama dengan salah satu fungsi uruf, yaitu menterjemahkan lafal. Dampak positifnya, penafsiran ini lebih sesuai dengan konteks uruf lokal di Indonesia di mana uruf di Indonesia mengatur undang-undang tentang Penghapusan Kekerasan Dalam Rumah Tangga. Yaitu Undang-Undang Republik Indonesia No. 23 Tahun 2004.

Konsep nafkah, nusyüż dan solusinya, konsep ketaatan dalam aturan fikih dan tafsir cenderung tidak sesuai dengan uruf Indonesia. Konsep tersebut ketika diterjemahkan sesuai dengan uruf saat ini, relatif lebih berpihak kepada suami ketimbang istri. Hal ini diakibatkan karena konsep-konsep tersebut muncul dari budaya patriarki yang cenderung mendomestikkan perempuan. Hubungan suami istri dianggap seperti antara hubungan bawahan dengan atasan. Padahal sejatinya, istri dan suami memiliki hak dan kewajiban yang seimbang.

Status seorang istri sebagai makmum dapat mengalami pergeseran makna dengan pergeseran atau perubahan uruf di masyarakat. Mayoritas istri pada masa klasik murni sebagai penerima nafkah dan dianggap tidak memiliki peran yang berarti dalam nafkah rumah tangga. Sementara pergeseran uruf dengan kemajuan modernitas menuntut perempuan untuk diberdayakan dan ikut serta dalam urusan publik yang beimplikasi kepada peran serta mereka dalam nafkah rumah tangga.

Peran perempuan dalam nafkah rumah tangga ini selayaknya juga memberikan peran dalam memimpin rumah tangga 


\section{Rausyan Fikr, Vol. 15 No. 1 Juni 2019: 23-62}

meski tidak sederajat dengan kepemimpinan laki-laki sebagai pemimpin rumah tangga. Apabila dalam dunia universitas dikenal istilah rektor dan pembantu rektor, dunia pemerintahan mengenal presiden dan wakil presiden, maka selayaknya perempuan dengan perannya dalam nafkah rumah tangga layak mendapatkan posisi sebagai pembantu pemimpin rumah tangga atau wakil pemimpin rumah tangga.

Berangkat dari alur berpikir seperti ini, maka dapat disimpulkan bahwa ketika dalam sebuah rumah tangga, istri ikut serta dalam nafkah rumah tangga-meskipun suami memliki keistimewaan kepemimpinan, maka hak kepemimipinan itu bisa saja menjadi milik bersama suami-istri, meskipun posisi istri masih belum setinggi hak kepemimpinan suami. Atau dengan kata lain, istri menjadi mitra atau wakil pemimpin rumah tangga.

Aturan nafkah dalam fikih dibangun atas uruf patriarki yang mendomestikkan perempuan. Sedangkan uruf saat ini, perempuan relatif berperan di ruang publik, mampu mandiri, bahkan relatif banyak yang memiliki penghasilan melebihi suami. Ketika uruf berubah dan berbeda dengan uruf ketika fikih ini disusun, aturan fikih nafkah yang dipahami dari nas yang berlaku umum dapat dikecualikan dengan uruf baru yang muncul kemudian (takhșiṣ al-'umūm bi al-'urfi al-târì).

Merujuk kepada uraian-uraian sebelumnya, hak dan kewajiban suami istri, khususnya mengenai konsep nafkah dan kepemimpinan membutuhkan penyesuaian dengan uruf yang berkembang. Penyesuaian dilakukan dengan tetap menjaga prinsip keseimbangan hak dan kewajiban suami istri. Karena sejatinya, hak istri tidak boleh diklaim secara apriori lebih rendah dari hak suami. begitu pun sebaliknya, kewajiban suami tidak boleh dianggap lebih berat atau lebih ringan dari suami. Artinya, setiap kali ada hak 
Harwis Alimuddin, Urf dan Implikasinya terhadap Kedudukan| 49

yang dikurangi pada salah satu pihak, maka pada saat itu pula ada hak yang dikurangi pada pihak lain. Beitupun sebaliknya.

\section{ANALISIS PENGARUH TERHADAP GUGURNYA NAFKAH ISTERI KARIR}

Kemajuan ilmu pengetahuan dan modernitas menuntut isteri untuk memiliki peran publik di masyarakat. Tuntutan kebutuhan rumah tangga modern membuat isteri harus keluar rumah, bekerja dan berkarier. Prinsip umum kebolehan isteri berkarier yang telah dijelaskan terdahulu adalah isteri boleh bekerja selama pekerjaan itu membutuhkannya atau dia membutuhkan pekerjaan itu dan selama melakukan pekerjaannya tetap menjaga prinsip-prinsip syariat.

Uruf menjadi latar belakang gugurnya nafkah isteri yang berkarier dengan pertimbangan-pertimbangan logis berikut ini:

Pertama: nafkah diwajibkan sebagai konpensasi penguasaan suami atas isteri yang menyebabkan isteri terisolir (ihtibās) yang dapat menjadikannya tidak bisa mandiri. Ketika isteri keluar rumah bekerja, isteri tidak lagi terisolir di dalam rumah. Selain itu suami dirugikan karena haknya untuk dilayani berkurang. Oleh kerena itu, isteri yang berkarier tidak wajib dinafkahi.

Kedua: kemumuan dalil-dalil yang mewajibkan menafkahi isteri ditakhșiṣ oleh uruf baru yang datang kemudian (takhṣis al'umūm bi al-'urfi al-țtärī). Sehingga uruf yang baru itu dikecualikan oleh keumuman dalil yang mewajibakan nafkah isteri. Oleh karena itu, uruf baru yang cenderung memberikan peran kepada isteri untuk berkarier dan aktif di ruang publik dikecualikan oleh keumuman dalil kewajiban menafkahi isteri yang dibangun atas uruf yang cenderung memposisikan isteri sebagai orang yang terisolir di dalam rumah. Dengan demikian, isteri yang berkarier tidak lagi wajib dinafkahi. 
Ketiga: kewajiban suami menafkahi isteri dibangun atas prinsip menjaga keseimbangan hak dan kewajiban suami isteri dalam rumah tangga. Ketika isteri keluar rumah bekerja, akan bermplikasi kepada ketidak seimbangan hak dan kewajiban dalam rumah tangga. Oleh karena itu, demi menjaga prinsip keseimbangan hak dan kewajiban suami isteri ini, maka perlu digugurkan hak nafkah isteri yang berkarier.

Keempat: kewajiban nafkah secara universal dibangun atas dasar ketidak mampuan orang yang dinafkahi. Ketika orang yang dinafkahi ini sudah mampu maka gugurlah kewajiban nafkahnya, seperti seorang anak wajib dinafkahi sampai dia berumur dewasa dan mampu mencari nafkah secara mandiri. Orang tua wajib dinafkahi ketika sudah uzur dan mulai melemah. Maka sudah semestinya, isteri yang berkarier tidak lagi wajib dinafkahi sebagaimana mereka (anak-anak dan orang tua) tidak wajib dinafkahi ketika mampu menafkahi diri sendiri.

Kelima: analisis yang lebih spesifik adalah, aturan nafkah dalam fikih dibangun atas uruf yang tidak mengenal penyatuan harta suami isteri (gono-gini). Oleh karena itu, tidak relevan apabila aturan nafkah itu diterapkan pada uruf yang mengaplikasikan uruf gono-gini. Semestinya aturan nafkah dalam fikih dibangun atas prinsip kemitraan suami isteri yang mengedepankan etika musyawarah dalam rumah tangga.

\section{ANALISIS PENGARUH URUF TERHADAP KEIKUSERTAAN ISTRI DALAM NAFKAH RUMAH TANGGA}

Perubahan uruf perempuan yang dahulu tinggal di rumah menjadi istri karier yang secara otomatis akan mengurangi hak posibilitas suami (tamkin) kepadanya. Dengan kata lain status istri karier akan berimplikasi terhadap ketidak seimbangan hak dan kewajiban suami istri. Oleh karena itu, perubahan uruf para istri 
Harwis Alimuddin, Urf dan Implikasinya terhadap Kedudukan| 51

saat ini dapat berimplikasi pada kedudukan nafkah istri yang berkarier.

Norma umum dalam nafkah rumah tangga, nafkah diwajibkan kepada suami karena suami yang bertanggung jawab atas terisolirnya istri (maḩbusah) untuk beraktifitas yang dapat menghasilkan finansial. Oleh karena itu, tidak logis ketika istri yang terbatasi ruang geraknya kemudian diberikan beban kewajiban nafkah, sementara istri tidak memiliki kesempatan seperti suami untuk mencari nafkah. Membebankan kewajiban nafkah ketika mereka tidak diberi kesempatan mencari nafkah sama saja dengan memberikan beban kepada sesuatu yang tidak disanggupi (al-taklifu bimā là yutaq). Sedangkan al-taklif bimā là yutaq ini bertentangan dengan prinsip syariah.

Perubahan uruf perempuan saat ini yang cenderung diberikan kesempatan untuk bekerja dan berkarier akan berimplikasi kepada ketidak seimbangan hak dan kewajiban istriyang telah menjadi prinsip umum dalam rumah tangga- ketika tanggung jawab nafkah itu hanya dibebankan kepada suami. Oleh karena itu, perubahan uruf ini semestinya beimplikasi kepada kewajiban keikut sertaan istri dalam nafkah rumah tangga yang diistilahkan dengan kewajiban atas dasar uruf. Untuk menjaga keseimbangan hak dan kewajiban suami istri, maka aturan kewajiban ini perlu dilegislasi dalam hukum postif, paling tidak dapat dijadikan sebagai salah satu muatan dalam Kompilasi

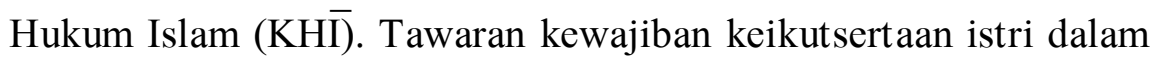
nafkah rumah tangga dapat diperkuat dengan beberapa alasan logis berikut ini:

1. Uruf yang berlaku di mayoritas masyarakat selama ini, istri yang bekerja ikut serta dalam nafkah rumah tangga. Istri yang bekerja apalagi berkarier relatif banyak yang ikut serta 
52 |Rausyan Fíkr, Vol. 15 No. 1 Juni 2019: 23-62

dalam nafkah rumah tangga. Bahkan ada yang keikutsertaannya dalam nafkah rumah tangga lebih mendominasi ketimbang suami. Oleh karena itu, peran istri yang bekerja dan ikut serta dalam nafkah rumah tangga, sudah sepatutnya diapresiasi dengan status hukum yang lebih konkret, yaitu kewajiban keikutsertaan mereka dalam nafkah rumah tangga.

2. Nas secara universal memerintahkan untuk saling tolong menolong, saling berbuat baik dan menjaga prinsip prinsip kemuliaan akhlak. Keikutsertaan istri yang berkarier dalam nafkah rumah tangga termasuk tolong menolong dalam kebaikan dan merupakan akhlak yang mulia.

3. Nas memerintahkan untuk meperlakukan pasangan dengan baik (al-mu'āsyarah bi al-ma'rüf). Tidak disangsikan lagi bahwa keikutsertaan istri dalam nafkah rumah tangga merupakan salah satu cara memperlakukan pasangan dengan baik dengan membantu beban tanggung jawabnya.

4. Rasulullah saw. memuji keikutsertaan Khadijah ra. Dalam nafkah rumah tangga. Pujian Rasulullah saw. menunjukkan kemulian keikutsertaan istri dalam nafkah rumah tangga. Ketika uruf Arab pada saat itu belum sekompleks saat ini dalam kebutuhan rumah tangganya. Uruf bekerja masih didominasi oleh suami. Sedangakan Khadijah sudah mendapatkan pujian dari Rasulullah saw karena keikut sertaannya dalam nafkah rumah tangga, maka ketika uruf berkarier bagi perempuan dan kebutuhan yang semakin kompleks, semestinya sudah saatnya keikut sertaan dalam nafkah rumah tangga bagi istri yang berkarier diwajibkan dengan pertimbangan kemaslahatan. Hadis yang menunjukkan pujian itu adalah Hadis Nabi saw: 


\section{Harwis Alimuddin, Urf dan Implikasinya terhadap Kedudukan| $\mathbf{5 3}$}

Diriwayatkan dari "Aisyah ra. berkata: ketika Nabi saw mengingat Khadijah, nabi memujinya sehingga saya pun berkata: apa yang membuatmu menyebut-nyebutnya sementara Allah swt. telah menggantikannya dengan yang lebih baik? Nabi saw menjawab: Allah swt tidak menggantinya dengan yang lebih baik, Khadijah telah mempercayaiku ketika orang lain sedang mendustakanku, Khadijah telah menafkahkan hartanya untukku ketika orang lain mengharamkan hartanya untukku dan Allah swt telah merezkikan anak kepadaku melalui Khadijah ketika Allah belum merezkikanku melalui istri-istri yang lain.

5. Peran dan posisi istri dalam rumah tangga adalah sebagai mitra dan bukan sebagai bawahan yang berfungsi sebagai pelayan sebagaimana uruf yang dipahami dalam masyarakat patriarki. Sebagai mitra kerja, maka sudah menjadi tanggung jawabnya ikut serta dalam nafkah rumah tangga

6. Ketika istri tidak ikut serta dalam nafkah rumah tangga dalam kondisi modern saat ini, akan berdampak pada kesulitan kaum lelaki untuk menikah. Karena kebutuhan rumah tangga modern saat ini sudah berbeda dengan kebutuhan rumah tangga dahulu. Pada masa klasik, kebutuhan primer rumah tangga belum sekompleks saat ini, sehingga pekerjaan suami masih memadai untuk memenuhi kebutuhan rumah tangga. Kebutuhan primer rumah tangga masih berkisar pada kebutuhan makanan, minuman dan pakaian. Tetapi saat ini, kebutuhan rumah tangga terutama di daerah perkotaan meningkat menjadi kebutuhan primer yang dahulu mungkin kebutuhan sekunder- bahkan kebutuhan tersier. Seperti kebutuhan biaya listrik, biaya cleaning service, biaya keamanan, biaya transportasi dan bahkan biaya telekomuniasi. Kondisi seperti ini menuntut 
54 Rausyan Fíkr, Vol. 15 No. 1 Juni 2019: 23-62

istri untuk wajib secara uruf ikut membantu mencukupi kebutuhan rumah tangga.

7. Uruf lokal di Indonsia mengakui eksistensi gono-gini sebagai ketentuan yang telah menjadi hukum positif. Oleh karena itu, keikutsertaan istri dalam nafkah rumah tangga cenderung lebih mudah diterima. Apabila terjadi perceraian, istri mendapat bagian yang sama dengan suami dari harta yang dikumpulkan bersama. Jadi, keikut sertaan istri dalam nafkah rumah tangga, sebenarnya turut membantu akselarasi harta gono gini yang terkumpulkan selama masa rumah tangga. Artinya, keikutsertaan istri dalam nafkah rumah tangga sebetulnya adalah untuk kemanfaatan dan kemaslahatan yang akan kembali kepada istri.

Sejauh penelusurun, Ibnu Hazm, sebagai tokoh penting dalam mazhab zahiristik berpendapat bahwa istri wajib ikut serta dalam nafkah rumah tangga. Menurut Ibnu Hazm, kata 'al-wāris' dalam QS. al-Baqarah 2/233 berarti 'ahli waris' dan istri termasuk ahli waris, maka istri pun berkewajiban memberi nafkah sesuai dengan redaksi ayat ini.Sementara menurut mayoritas ulama maksud dari 'wa 'alā al-wāris' dalam ayat ini adalah kewajiban nafkah diwajibkan kepada suami dan juga diwajibkan kepada ahli waris dari kalangan laki-laki yang wajib menafkahinya.

\section{ANALISIS PRINSIP KEMITRAAN SUAMI ISTRI DALAM RUMAH TANGGA}

Konsekuensi dari prinsip keseimbangan dalam hak dan kewajiban suami istri dalam rumah tangga adalah adanya kemitraan antara suami dan istri dalam rumah tangga. Prinsip kemitraan ini dapat terwujud apabila ada keseimbangan antara hak dan kewajiban, ada kesetaraan antara suami dan istri dalam 


\section{Harwis Alimuddin, Urf dan Implikasinya terhadap Kedudukan| 55}

peranan dan kesempatan yang dilandasi dengan sikap saling menghormati dan saling tolong menolong dalam berbagai lini kehidupan. Karena pada dasarnya, nas secara universal menginginkan laki-laki dan perempuan saling menghormati dan saling tolong menolong sesuai dengan kodrat dan kapasitasnya.

Prinsip kemitraan yang dimaksudkan di sini, bukan menempatkan istri lebih mendominasi suami dalam urusan rumah tangga. Prinsip kemitraan yang dimaksudkan di sini justru akan menghilangkan dominasi itu. Sama saja apakah dominasi itu dari suami atau dominasi istri. Karena dominasi dalam rumah tangga bertentangan dengan prinsip keseimbangan hak dan kewajiban dalam rumah tangga. Dominasi akan akan berimplikasi pada pengingkaran kewajiban dan klaim atas hak.

Karena sejatinya, spirit teks-teks syariah menolak segala bentuk dominasi, eksploitasi dan penindasan. Risalah yang dibawa oleh Rasulullah saw. adalah untuk membebaskan ummat manusia dari segala bentuk ketimpangan dan ketidak adilan sosial. Alquran bahkan menyerukan ummat manusia untuk membela kaum lemah dan tertindas. Sebagaimana dalam QS. al-Nisā/4: 75.

Nas yang kerap kali dijadikan sebagai piranti justifikasi atas superior suami di atas istri adalah QS. al-Nisa 4/34. Kata 'qawwām' (pemimpin) yang termuat dalam ayat ini, seringkali dijustifikasi bahwa suami selalu mendominasi istri di dalam rumah tangga. Padahal menurut Quraish Shihab, seseorang yang melaksanakan tugas atau apa yang diharapkan darinya dinamai qāim. Kalau dia melaksanakan tugas itu sesempurna mungkin, berkesinambungan dan berulang-ulang dia dinamai qawwām. Menerjemahkan kata 'qawwäm' dengan pemimpin belum menggambarkan seluruh makna yang dikehendaki, meskipun harus diakui bahwa kepemimpinan merupakan satu aspek yang 
dikandungnya. Atau dengan kata lain, dalam pengertian 'kepemimpinan' tercakup pemenuhan kebutuhan, perhatian, pemeliharaan, pembelaan, dan pembinaan. Oleh karena itu, perlu digaris bawahi bahwa qawwāmah (kepemimpinan) yang dianugerahkan oleh Allah swt. kepada suami tidak boleh mengantarkannya kepada kesewenang-wenangan. Karena Alquran menganjurkan musyawarah dalam menyelesaikan setiap persoalan yang dihadapi keluarga.

Ketika Alquran menetapkan tugas kepemimpinan itu, hal tersebut dinyatakan sebagai sebagai sebab dari dua hal pokok. Pertama: karena adanya keistimewaan yang berbeda pada masingmasing jenis kelamin, tetapi dalam konteks qawwāmah keistimewaan yang dimiliki oleh laki-laki lebih sesuai untuk menjalankan tugas tersebut dibandingkan perempuan. Kedua: Kerena para suami telah menafkahkan sebagian harta mereka. Hal ini berarti jika keduanya, yakni kemampuan qawwāmah dan kemampuan member nafkah, tidak dimiliki oleh seorang suami, atau kemampuan istri melebihi kemampuan suami dalam hal keistimewaan-misalnya karena suami sakit-bisa saja kepemimpinan rumah tangga beralih kepada istri, tetapi ini dengan syarat kedua faktor di atas tidak dimiliki oleh suami. Jika suami tidak mempu memberi nafkah tetapi tidak mengalami gangguan dari segi keistimewaan yang dibutuhkan dalam kepemimpinan, istri belum boleh mengambil alih kepemimpinan itu.

Berangkat dari alur berpikir seperti ini, dapat disimpulkan bahwa ketika dalam sebuah rumah tangga, istri ikut serta dalam nafkah rumah tangga, hak kepemimipinan itu bisa saja menjadi milik bersama suami-istri, meskipun posisi istri masih belum setinggi hak kepemimpinan suami. Atau dengan kata lain, istri menjadi mitra bagi suami dalam menjalankan urusan rumah tangga. 
Harwis Alimuddin, Urf dan Implikasinya terhadap Kedudukan| 57

Apabila dalam dunia akademik dikenal rektor dan pembantu rektor sebagai mitra kerjanya, di dalam dunia pemerintahan dikenal presiden dan wakil presiden sebagai mitra kerjanya, maka di dalam rumah tangga semestinya suami sebagai pemimpin rumah tangga menjadikan istri sebagai wakil pemimpin rumah tangga atau pembantu pemimpin rumah tangga sebagai mitra kerjanya. Praktiknya, tugas-tugas rumah tangga adalah tugas bersama suami istri, meskipun suami tampil sebagai pemimpin utama, istri pun dengan cara dan kapasitasnya turut mengambil peran sehingga tugas-tugas rumah tangga dapat terselesaikan dengan baik. Ketika istri mendapatkan posisi sebagai mitra bagi suami, sudah selayaknya suami bermusyawarah dengan istri dalam setiap kebijakan-kebijakan prinsipil yang akan ditempuhnya. Kebijakannya itu pun sepatutnya mendapat persetujuan dari isteri. Termasuk didalamnya keputusannya untuk berpoligami harus mendapatkan persetujuan isteri.

\section{PENUTUP}

Hak dan kewajiban suami istri yang diderivasi dari nas sejatinya memiliki bobot yang sama. Kewajiban suami tidak bisa diklaim secara apriori lebih berat daripada kewajiban istri. Demikian halnya istri tidak bisa dikatakan memiliki tanggung jawab yang lebih berat daripada suami. Oleh karena itu, dalam menjalankan hak dan kewajiban suami istri perlu menempuh jalan musyawarah dengan mengadaptasikannya dengan uruf masyarakat yang berlaku. Karena ternyata, dari 23 ayat Alquran tentang hak dan kewajiban suami istri, 10 di antaranya diiringi dengan kata ma'rüf yang merupakan pecahan kata dari kata al'urf(uruf). Fakta itu, bukan karena kebetulan tetapi karena Syāri' menghedaki hak dan kewajiban suami istri itu diadaptasikan dengan uruf yang berlaku, dengan catatan tetap menjaga prinsip keseimbangan hak dan kewajiban suami istri. Ada dua hal pokok dalam hak dan 


\section{Rausyan Fikr, Vol. 15 No. 1 Juni 2019: 23-62}

kewajiban suami istri yang perlu diadaptasikan dengan uruf dengan tetap menjaga prinsip keseimbangan, yaitu hak nafkah istri (kewajiban suami menafkahi) dan hak kepemimpinan atau qawwāmah suami (kewajiban istri mematuhi). Adaptasi itu akan berkonsekuensi logis terhadap permasalahan-permasalahan yang lain. Khususnya masalah penyatuan harta (gono-gini) dan juga masalah izin poligami.

Istri yang berkarier tidak wajib dinafkahi. Konsekuensi logisnya, istri yang berkarier meningkat statusnya dari orang yang dipimpin oleh suami menjadi mitra bagi suami dalam memimpin dan mencari nafkah rumah tangga. Selain itu, karena istri menjadi mitra bagi suami dalam memimpin dan mencari nafkah, maka dikenal adanya penyatuan harta suami istri (gono-gini), karena keduanya sama-sama bekerja mencari nafkah. Selanjutnya, suami tidak lagi bebas berpoligami tanpa izin istri, karena istri adalah mitra, di mana segala keinginan-keinginan prinsipil kedua belah pihak harus didiskusikan dan mendapat persetujuan besama.

\section{DAFTAR PUSTAKA}

'Abdu al-Bāqì, Muḥammad Fu'ad. al-Mu'jam al-Mufahras li Alfāz al-Qur'ān al-Karim, Maktabah Daḥlān, t.th

'Abduh, Syeikh Muhammad. Tafsìir al-Manār. al-Qāhirah, Dār alManār, Cet. II, 1366 H/ 1947 M), Vol II.

'Abdul 'Azīz Muḥammad 'Azzām. Al-Qawāid al-Fiqhiyyah. alQāhirah: Dār al-Hadisis, 2005.

Abū Zahrah, Muhammad. Ușūl al-Fiqh, al-Qāhirah: Dār al-Fikr al'Arabī, 2006. 
Harwis Alimuddin, Urf dan Implikasinya terhadap Kedudukan| 59

Alyasa'Abubakar. Metode Istislahiah; Pemanfaatan Ilmu Pengetahuan Dalam Ushul Fiqh, Cet. I, Jakarta; Prenadamedia Group, 2016.

Būṭi, Muhammad Sa'ìd Ramaḍān. Dawābit al-Mașlaḥah fí alSyariah al-Islāmiyyah, Cet X; Dimasyq: Dār al-Fikri, 2010. al-Mar'atu baina Tugyān al-Nizam al-Garbī wa Latăif al-Tasyrì' al-Rabbānì, Bairūt: Dār al-Fikr alMu'āṣir, t.cet., t. th.

Fairūzābādi, Majduddin Muhammad Ibnu Ya'qūb. Al-Qāmus alMuḥiț, Tahqiq Muhammad Na'īm al-Arqasūsì, Bairūt: Muassasah al-Risālah, Cet. VIII 1426 H/2005 M.

Hamzah, Riqābah al-Qada' a'la al- 'Urfi, Dirāsah Muqāranah baina al-Syari'ah wa al-Qānūn, Dimasyq: Majallah Jāmi'ah Dimasyq li al'Ulūm al-Iqtiṣādiyyah wa al-Qānūniyyah. 2008.

Ibnu 'Asyūr, Muḥammad al-Ṭāhir. Tafsìr al-Taḥrì wa al-Tanwï, Tūnis: al-Dār al-Tūnisiyah li al-Nasyr, 1984.

Ibnu Ḥanbal, Imām Aḥmad ibnu Muḥammad. al-Musnad, disyarah oleh Hamzah Ahmad al-Zain, al-Qāhirah: Dār al Ḥadits, Cet. I, 1416 H/ 1995 M.

Ibnu Hazm, ĀTi Ibnu Aḥmad Ibnu Sa’īd. al-Muhalla, Miṣr: Idārah al-Ṭibā' ah al-Munirah, $1352 \mathrm{H}$.

Ibnu Kas̄ir al-Dimasyqi, al-Ḥafidz Imāduddin Abu al-Fidā Ismā'il. Tafsìr al-Qur'ān al-'Azīm, tahqiq Musțāāa Sayyid Muḥammad, Muḥammad Sayyid Rasyād, al-Qāhirah, Muassasah Qurtubah, Cet. I, 1421 H/ 2000 M. 
Ibnu Qayyim al-Jauziyyah, Abū 'Abdullāh Muḥammad Ibnu Abū Bakr Ibnu Ayyūb. 'Ilām al-Muwaqqi īn 'an Rabb alĀlamīn, Riyāạ: Dār Ibnu al-Jauzìi, 1423 H.

Jurjānī, ‘Āli Ibnu Muḥammad Sayyid al-Syarif. Mu’jam al-Ta’rifăt, Tahqī wa al-Dirāsah Muhammad Siddiq al-Minsyāwi, alQāhirah: Dār al-Fađ̣ilah, t.cet., t.thn.

Lahmuddin Nasution, Pembaharuan Hukum Islam Mazhab Imām Syāfi 'î, Bandung: PT Remaja Rosdakarya, 2001.

Lajnah min Asātizah Qism al-Fiqhi bi Kulliyyah al-Syarī' ah wa alQānūn bi al-Qāhirah Jāmi'ah al-Azhar, Muḥạuarāt fi alAḥkām al-Muta'alliqah bi Fiqhi al-Usrah 'alā Mazhab alImām al-Syāfíi i, al-Qāhirah: Jāmi'ah al-Azhar, 1427 $\mathrm{H} / 2007 \mathrm{M}$.

Marāgī, Aḥmad Muștāāā. Tafsīir al-Marāgi, Miṣr: Syarikah Maktabah wa Maṭba'ah Muștāăa, Cet I, 1365 H/ 1946 M.

Musțafā al-Sibā'i, al-Mar'ah Baina al-Fiqhi wa al-Qānūn (Bairūt: Dār al-Warrāq, Cet VII, 1420 H/ 1999 M

Naisabūrì, Muḥammad al-Ḥākim. Mustadrak 'Alā al-Ṣaḥīhain Bairūt: Muassasah al-Risālah, 1999.

Nawawī, Abū Zakariyyā Mahyu al-Dīn Ibnu Syaraf. Șahīh Muslim, (Beirut: Dārul Ma'rifah li al-Ṭibā'ah wa al- Nasyar wa al-Tauzī', 1999.

Pusat Bahasa Departemen Pendidikan Nasional, Kamus Bahasa Indonesia, Jakarta: Pusat Bahasa, 2008.

Quraish Shihab, M. Wawasan Alquran: Tafsir Maudhu'i Atas Pelbagai Persoalan Umat, Bandung: Mizan, Cet VIII, 1419 H.1998 M. 
Harwis Alimuddin, Urf dan Implikasinya terhadap Kedudukan| 61

------------------------. Perempuan- dari Cinta sampai Seks, dari Nikah Mut'ah sampai Nikah Sunnah, dari Bias Lama sampai Bias Baru, Jakarta: Lentera Hati, Cet IV, 1428 H/ $2007 \mathrm{M}$.

Keserasian Alquran, Jakarta: Lentera Hati, 2002.

Qurțubī, Abū 'Abdullāh Muhammad Ibnu Aḥmad Ibnu Abū Bakr. al-Jāmi' li Ahkām Alquran wa al-Mubayin Limā Tadammanahū min al-Sunnah wa $\overline{A y i}$ al-Furqān, Tahqīiq Duktūr 'Abdullah Ibnu 'Abdu al-Muhsin al-Turkì, Bairūt: Muassasah al-Risālah, Cet. I, 2006 M/ 1427 H.

Ridwan. Hukum Islam dan Perubahan Sosial, Ibda': Jurnal Studi Islam dan Budaya, 2007.

Sābiq, Sayyid. Fiqh al-Sunnah, al-Qāhirah: al-Fatḥ li al-I'lām al'Arabi, t. th.

Soerjono Soekanto, Hukum Adat Indonesia, Jakarta: Rajawal Pers, Cet. Ke 13, 2013.

Suki Ali. Global Feminist Politics: Identities in Changing World, New York: Routledge, 2000.

Suwailam, Wafa' bintu 'Abdu al-Azìis. al-Qawwāmah wa Ahkāmuhā al-Fiqhiyyah, Dirāsah Fiqhiyyah Muqāranah, Majallah al-Jam'iyyah al-Fiqhiyyah al-Saūdiyyah, t.cet. t. thn.

Syātịbī, Abū Isḥāq. al-Muwāfaqāt fî̀ Ușūl al-Syarī 'ah. al-Qāhirah: al-Maktabah al-Taufiqiyyah, 2003.

Syaḥrūr, Muhammad. Naḥwa Ușulin Jadidah li al-Fiqhi al-Islāmī, Fiqh al-Mar'ah - al-Wașiyyah, al-Irś, al-Qawwāmah, al- 
62 Rausyan Fikr, Vol. 15 No. 1 Juni 2019: 23-62

Ta'addudiyyah, al-Libās, Dimasyq: al-Ahāli li al-Ṭibā'ah wa al-Nasyr wa al-Tauzì', cet. 1, 2000.

Syamsul Arifin, dkk, Spiritualisasi Islam dan Peradaban Masa Depan, Yogyakarta: Sipress, 1996.

Uways, Abdul Halim. Fiqh Statis Dinamis, Bandung: Pustaka Hidayah, 1998.

Zamakhsyarì, Abū al-Qāsim Maḥmūd Ibnu 'Umar. al-Kasysyāf 'an Haqāiq al-Gawāmid al-Tanzīl wa 'Uyūn al-'Aqāwil fí Wujūh al-Ta'wīl, Tahqiqiq Syeikh 'Ādil Ahmad al-Maujūd wa 'Āli Muhammad Mu'awwid, Riyāḍ: Maktabah alAbīiān, Cet I, 1418 H/1998 M.

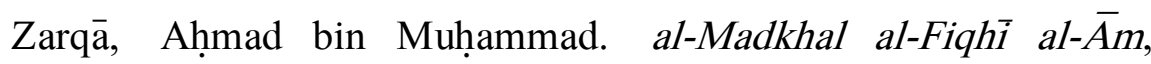
Dimasyq: Dār al-Qalam, Cet. II, 2004 M, 1425 H/ 2004 M.

Zuhailì, Wahbah. al-Fiqhu al-Islāmi wa Adillatuhū; al-Syāmil li alAdillah al-Syar'iyyah wa al-Arā al-Mazhabiyyah wa Ahammu al-Nazariyyāt al-Fiqhiyyah wa Tahqiqu al-Ahadis al-Nabawiyyah wa Takhrījuhā, Sūriyyah: Dār al-Fikr, Cet III, $1405 \mathrm{H} / 1985 \mathrm{M}$.

Cet. I; 1406 H/ 1986 M.

https://.wikipedia. org/wiki/Grant_Thornton_LLP/.

https://www.cnnindonesia.com/gaya-hidup/20160308121332-277-

116053/wanita-karier-indonesia-terbanyak-keenam-didunia/ 